\title{
Russian legal tradition
}

\author{
I. Yu. Kozlikhin', V. V.Pugachev', O.A.Zayachkovskii ${ }^{2}$, D. Szpoper ${ }^{3}$ \\ ${ }^{1}$ St. Petersburg State University, \\ 7-9, Universitetskaya nab., St. Petersburg, 199034, Russian Federation \\ 2 Immanuel Kant Baltic Federal University, \\ 14, A. Nevskogo ul., Kaliningrad, 236016, Russian Federation \\ ${ }^{3}$ Pomeranian Academy in Slupsk, \\ 22A, Arciszewskiego ul., 76-200, Poland
}

For citation: Kozlikhin, Igor Yu., Pugachev, Valerii V., Zayachkovskii, Oleg A., Szpoper, Dariusz. 2019. "Russian legal tradition". Vestnik of Saint Petersburg University. Law 4: 815-826. https://doi.org/10.21638/spbu14.2019.413

The purpose of this article is to discuss the traditional attitudes towards law which have been dominant in Russian society at different periods of its history. The article demonstrates the sources and causes of paternalism reinforcing the casual link between legality and obedience in the minds and practices of the Russian political authorities. Special attention is paid to the views on private property which took hold among the key Russian political thinkers of the late nineteenth and the early twentieth centuries, such as V.S. Solovyov and V. V. Rozanov, and the related state of the limited development of the Russian civil society in the late imperial era and throughout the Soviet period. In relation to this, an assumption is made that the attitude of the Bolsheviks to law and state was a crude form of continuing this contiguous tradition. In order to support these theses, a comparative analysis of the views of L. D. Trotsky and E. B. Khokhlov on the organization of labor during the first years of the Soviet regime is provided. The authors argue that the emergence of the early Soviet doctrine of the militarization of labor and the concomitant bureaucratic system of labor management was due to the authorities' desire to centralize the distribution of factory production under the planned economy and the substantial public ownership of industry. A gradual change of social consciousness and practices during the recent decade - a trend that could not avoid affecting the current state of Russian legal studies and political thought - is thoroughly emphasized.

Keywords: law, state, paternalism, property, morals, labor, contract, coercion, freedom.

1. Introduction. For centuries, Russia has been developing independently from the rest of continental Europe, with the beginning of her regular political contacts with the West dating back to no earlier than the Middle Ages. Throughout this time, a unique legal tradition, legal culture and a special sense of justice have been emerging among the Russians. According to a number of modern researchers, a characteristic feature of the Russian legal tradition is, among other things, state paternalism and the neglect of private property. This article aims to trace the peculiarities of the historical development of the main elements of the Russian legal tradition in the era which witnessed the decline of the traditional Russian statehood - an era when a number of Bolshevik thinkers and, above all, Leon Trotsky, openly admitted to coercion being the core feature of the Russian legal tradition for the first time in her history.

(c) Санкт-Петербургский государственный университет, 2019 
2. Main text. We shall start with outlining the concept of state or, to put it more accurately, the way Russian political consciousness perceives the notion of a "proper" state, rather than with laying down general ideas about the law which traditionally prevail in Russia.

When a word (a term) crops up naturally without having been previously borrowed from a foreign language (as is the case, for instance, with the word moderator - a kind of a funny word for the Russian-speaking audience, to say the least), it is no doubt that it actually denotes the essence of a thing. As we grasp the meaning of a term in question, the gist of the matter becomes clear to us. To convey the idea of a state, some European languages, notably English, French, Italian, and German, use the words state, état, stato, and staat, which are essentially derivatives from the Latin word status (i. e. condition) - a term quite bereft of any emotional context whose function is to underscore rationality in the way the state is perceived. In most cases, such a "rational" state is nothing but a product of human efforts devoid of any mystical overtones. This is where different contract theories of state origin, as well as the whole notion of the rule of law, stem from.

As regards Russia, specificities of its political history are such that it has never been able to fully reconcile its political culture with the original Latin fundamentals, with the word "state" (Rus. gosudarstvo) being paronymous with "Lord" (Rus. Gospod'). It is only after having thrown off the yoke of the Golden Horde that the independent Russian state came into being. As noted by Vladimir Tomsinov, "Rus' emerged from the ruins left as a result of the Tatar-Mongolian pogrom, leaping once again into the world history arena as an independent power so as to live a self-sufficient life in accordance with its mission. Under these circumstances, the purpose of the Russian legal-political ideology was to promote awareness of the new Russian state's independence and might among the Muscovite politicians and the European ruling circles" (Tomsinov 2003, 74). This, in fact, was the point the confrontation between Russia and Europe bolstered by the mutually irreconcilable views on the character and aims of state authority began at. "The Russian czars receive their power from God" - this has been the most certain and incontestable tenet since the times of Ivan the Terrible. "It is in line with the Russian political ideology that the czar bears responsibilities with regard to his subjects by virtue of his title rather than under the contract of rulership... As a bearer of a lofty title, the Russian czar was supposed to meet manifold criteria required to exercise his authority, as well as to discharge multiple duties towards his subjects - in short, to do everything under the umbrella of a "historical mission" summarized in a motto: "to serve Russia and God, to serve God and Russia" (Tomsinov 2003, 144-145). So we have the Lord (Gospod') - the master (gospodin) - the sovereign (gosudar') - the state (gosudarstvo) (for details, see: Kharkhordin (ed.) 2002). Thus, the sovereign receives his authority from God, and this authority is akin to that of a father and a master. Having described himself as the "master of the Russian land", Nicholas II did not commit a sin against the truth, at least against his understanding thereof (although he himself failed to fulfill his duties thoroughly to the end). "The Russian land cannot exist without a czar" - the proverb says. With the unlawful abdication of Nicholas II, the Russian Empire collapsed. Speaking on the developments which had taken place during the Times of Troubles, Fedor Taranovsky wrote: "It has never been possible to build Russian land without a sovereign, for he is the embodiment of political self-sufficiency and independence of the people... After a series of failed experiments and long searches, the painful and threatening problem was finally resolved as the 
council elected Mikhail Fedorovich Romanov to rule the Czardom of Russia. He was the one to recover the supreme authority from ruins, as well as to instill law and order in the state. Under his aegis, the time-honored monarchical rule was re-established in Moscow" (Taranovsky 2004, 83). It is evident that this kind of relationship between the rulers and the ruled is essentially of extra-legal nature - in a way reminiscent of relations between the members of a family.

In Russia, as in China (although in China to a greater extent), the state is identified with a large family headed by a pater (a father). In this kind of setup, the legal principle of formal equality is virtually unattainable, for it is rejected by the very essence of family relations. Similar is the case with any attempts at restraining paternal authority on the external level. The father is the one who restrains himself or rather executes his duties the way he understands them. Long story short, the paternal ruler is omnipotent. That is why it is expected that the people address him with all their troubles, wishes, and requests. The kind ruler is supposed to be unrestrained in doing good deeds, while the evil one is also unrestrained in his evildoing. At the same time, since it is deemed absurd and harmful at the very least to curb and regulate the sovereign's virtues, he (no matter the formal title he bears) is by no means supposed to act in accordance with the law of the land. That is why it is quite unlikely that the famous statement made by Charles Montesquieu, who claimed that even virtues had need of limits, would find support in the hearts of Russians. Virtue knows no limits. It is an ancient Russian tradition to address requests to the sovereign. Believing it certain that the power of the emperors was boundless, Leo Tolstoy and Vladimir Solovyov, the greatest representatives of Russian culture, both addressed letters to them. Leo Tolstoy suggested that Alexander III forgive those who had murdered his father, give them money and send them to America, while it was again his suggestion that Nicholas II end the private ownership of land. Vladimir Solovyov believed that just a single word of Czar Nicholas II would be enough for the freedom of conscience and religion to prevail in Russia. The tradition of writing letters to supreme authorities has been as alive throughout the Soviet era (take, for instance, the flow of letters to Stalin during his reign) as it is alive today: numerous and diverse appeals to the president confirm this. The fact that to comply with many such requests (for example, to grant a pardon to one of the perpetrators in a criminal case) entails a violation of the law does not usually bother anyone except for the president. At the same time, many requests are often considered and approved by the president, although it is not even among his duties to consider them. Why is this happening? The answer to this question is plain and simple. Public authority always tends to conform to public expectations, which are the major source of its legitimacy. As long as these expectations exist, the public authority is bound to behave in accordance with them.

Why the requirement that authority should abide by the law is not among the most crucial ones then? As we all know, the basic institution of private law is property. It is the property that all the other institutions of civil law and, indirectly, all the other branches of law are based on. Historically, it is this legal institution that failed to evolve sufficiently to flourish on the Russian soil. There are a lot of reasons for that, with the main reason being communal land ownership. The deep-grounded belief that land cannot be privately owned has traditionally been espoused by many Russians, including Leo Tolstoy, a fact that has been pointed out many times by numerous researchers, among whom, as it seems, Richard Pipes appears to be the most insightful. Below is a rather long quote from one of his books giving an exhaustive summary of the problem: "An object of property claims 
must meet two criteria: it has to be desirable, and available only in limited supply. For people who support themselves primarily by agriculture, this object is arable land...The surfeit of land in Russia prior to the nineteenth century had two important effects. In the first place, it led to the underdevelopment of all those institutions which in regions where land was in short supply produced civil societies: for where land is scarce, the local population is compelled to devise ways of resolving peacefully conflicts over it...Secondly, the seemingly inexhaustible profusion of land prior to the nineteenth century impressed on the Russian peasant the conviction that the soil, like water and air, was res nullius which God had created for everyone's benefit and which, therefore, could not be owned. Everyone was free to use it, but no one could claim exclusive title to it. One could appropriate only that which one grew or made: since no one made the land, no one could own it. In the mind of the Russian peasant, the forest was common possession but lumber belonged to him who had cut it. This outlook, quite typical of primitive societies, in the case of Russia outlasted the era of abundance and retained its hold on the peasant's mind into the early twentieth century, when, owing to rapid population growth and the end of territorial expansion, arable soil became scarce" (Pipes 2000, 212-213).

It is ownership in general rather than just land ownership that has been perceived negatively by the Russians. It has generally been shameful to be a proprietor. But why did it have to be like that? In 1909, Vasilii Rozanov wrote: "In Russia, all the property has been acquired either through begging, or as a result of a donation, or by means of theft. There are very few instances of property acquired through hard work, and this is why the property is neither lasting nor respected" (Rozanov 1990, 216). This notion has currently become even more relevant than ever before. This attitude towards private ownership, if not totally mistrustful (although never totally negative), has seriously affected the legal awareness of the Russian society in its entirety.

The process of shaping the specific sense of ownership that Vasilii Rozanov characterized was very complex and different for selected provinces of the Russian Empire, including Western Krai. In this context, there was an important discussion among the gentry inhabiting the western governorates of Russian Empire, that took place half a century earlier, before the peasants' reform, that came into force in 1861. Among the elements that caused great anxiety among landowners, one of the prepared legal norms must be indicated. This order assumed a forced sale of peasants' farms, which are part of the landowners' property. In 1858 a landowner from the Kaunas province, Jakub Gieysztor, described these norms as a blow aimed at the idea of the legal order, which sooner or later had to cause fatal consequences (Szpoper 2003, 167).

The development of the sense of ownership in the second half of the nineteenth century in the Western Krai was limited as a result of political decisions that followed the January Uprising of 1863. The government authorities in the Western Krai, wishing to lead to the deconstruction of social relations, sought to implement a policy in which peasants played a key role. According to the concept of Vilnius general-governor Michail Muraviov, the emancipation of the peasants and their gradual enfranchisement were to hit the economic status of the Lithuanian nobility. On the other hand, the same official did not believe in the full implementation of the objectives that the peasants reform of 1861 would achieve. In his opinion, one of the reasons was the demanding attitude of the peasants and the phenomenon of their underestimation of the main provisions of the peasants' reform - personal freedom and possession of small pieces of land (Tarkowski 2018, 189). 
There is still another important feature of the Russian legal tradition, namely the omnipresent contraposition of law, on the one hand, and morals, on the other. Both Georg Jellinek and Vladimir Solovyov believed the law to be nothing but a moral minimum, a bare minimum required for ethical behavior. However, each of them understood these concepts quite differently from the mainstream view. Whereas Vladimir Solovyov maintained that the more perfect the moral conditions of a society, the less legal regulation needed, Georg Jellinek believed that the more developed a society, the more legal rules needed. According to Jellinek, the law had nothing to do with the existence of evil, as Solovyov believed, but it was an indispensable means of regulating complex social relations.

As of today, the views propounded by Vladimir Solovyov as to the essence of law (typically Russian views, as one may note) are still alive and well. The following excerpt is from a document entitled "The Basis of the Social Concept [as proposed by the Russian Orthodox Church]": "The aim of earthly law is to be a manifestation of the universal divine law in the realm of politics and society. At the same time, being a product of historical evolution, every legal system developed by the humankind carries a seal of boundlessness and imperfection... Law contains a certain minimum of moral standards compulsory for all members of society. The aim of secular law is not to turn the evil world into the kingdom of God, but to prevent it from turning into hell" (The Russian Orthodox Church n. d.).

Unlike Russia where ethics usually dominate over the law of the land, it is not characteristic of the Western legal tradition to contrast law with morals (for it is generally deemed moral to observe legal rules). At the beginning of his famous article, In Defense of Law, Bogdan Kistiakowsky states as follows: "Law cannot go next to such values as scientific truth, moral perfection, or a religious shrine" (Kistiakowsky 1990, 122). Although Kistiakowsky was no doubt a brilliant legal theorist, he actually failed to resist the temptation to put the law in its place while making attempts to protect it. But why should one compare law with scientific truth, ethics, or religion? No way can math, despite the fact that it is definitely among the "grand" sciences, be put neither below nor above the level of the law, for they are different branches of knowledge that never intersect. Ethics, religion, and law are, sure enough, connected to one another, reinforcing each other (as is the case with the Protestant states) or crashing into each other (the case of Russia and China). Still, the tasks before them are quite different. In the excellent words of Charles Montesquieu, "such a being (i. e. man. - Authors) might every instant forget his Creator; God has, therefore, reminded him of his duty by the laws of religion; such a being is liable every movement to forget himself; philosophy has provided against this by the laws of morality; formed to live in society, he might forget his fellow creatures; legislators have, therefore, by political and civil laws, confined him to his duty" (Montesquieu 1955, 165).

In the absence of a developed civil society, the notion of law is almost exclusively associated with violence and immorality. Apart from that, authorities tend to believe that violence might be beneficial to their societies. As aptly noted by Maximilian Voloshin:

Peter the Great was the first Bolshevik,

Scheming to send Russia,

Despite her inclinations and customs,

Reeling ahead hundreds of years into her future.

$\mathrm{He}$, as we, knew no means different, 
From decree, execution and torture chamber,

To realize Truth on earth.

(Translated by Steven Richmond, University of Chicago, Department of History)

The October Revolution of 1917 is often looked upon as a complete break with the past and the beginning of a new, "soon-to-be-wonderful" era - at least this is what the Bolsheviks believed it to be. But this was not the case. Maximilian Voloshin was right when he declared that the Bolsheviks had failed to invent anything new in the realm of politics. In their building of a new society, the Bolsheviks resorted to the same old wellestablished instruments, including coercion, violence, and terror. It was up to them to decide whether to give their actions any legal form or not. Adopted on December 10, 1918, the Soviet Labor Code, which was the second ever Soviet code of law (the first being the Code on Marriage, the Family and Guardianship adopted on September 16, 1918), serves well to demonstrate this. As regards the Code on Marriage, the speed of its promulgation is quite understandable, for the desire of the state has always been to have births, deaths, and marriages registered properly. Apart from that, the reason for its having been promulgated so fast might have been the Bolsheviks' yearning for diminishing the influence the Church wielded over social life. But why were they so fast to enact the Labor Code? According to a 1971 textbook titled History of the State and Law of the USSR, "the Labor Code of the USSR, promulgated on December 10, 1918, was an attempt to combine all the previously created laws on labor protection in a single code. In this code, all the major principles of socialist labor management were consolidated, which was the reason behind its immense political significance. The code exemplifies the outstanding achievements the working class wins when they rise to power. Workers from multiple capitalist countries have shown great interest in the Labor Code, which is evidenced by its translation into dozens of foreign languages" (Chistiakov, Kukushkin 1971, 136). From here, the only conclusion that we may draw is the following: the Labor Code is a code on labor protection devised thanks to the efforts of the working class who have seized the reins of power; workers of the whole world envy the workers of Soviet Russia. The authors of the textbook, nevertheless, failed to hide the fact that the first section of the code was entitled "On labor conscription". Still, the authors seem to have found a quite easy way out of this delicate situation. According to them, labor conscription "falls with all its weight on the exploiting classes" (Chistiakov, Kukushkin 1971, 136). This is clear slyness; still one should not reproach the authors of the textbook for tricking their audience since they were forced to act like that under the pressure of the then-current political conditions. Now, for the purpose of analyzing the ideas behind the organization of labor, we shall address Terrorism and Communism, a book written by Leon Trotsky in 1920 (chapter eight "Problems of the Organization of Labor" to be exact), on the one hand, and Theory and Practice of the Organization of Labor during the Early Years of the Soviet Regime, an article published by Evgenii Khokhlov in 2010, on the other. Both these authors are experts in their field unrestrained in voicing their opinions by no political boundaries whatsoever. Both of them are perfectly honest with their readers.

We shall start with the book by Leon Trotsky. By his own admission, the eighth chapter of the book comprises his numerous minor works, as well as speeches before the labor union congresses, supreme soviets of the national economy, and the Ninth Congress of the 
Russian Communist Party. It appears, therefore, that by the time of the book's first release, Trotsky had long been voicing his ideas about the organization of labor on different occasions and before different audiences without ever being faced with any objections. An initial comment on this point would appear necessary: it is highly revealing that his book on the organization of labor is the very same book wherein he, in the heat of polemics against Karl Kautsky, stresses the necessity and advisability of terror for achieving the ultimate goals of communism. There was little doubt among the Bolsheviks concerning the permissibility of terrorism during the initial years of Soviet power.

So, here is what the Labor Code was needed for. "The organization of labor is in its essence the organization of the new society: every historical form of society is in its foundation a form of organization of labor. While every previous form of society was an organization of labor in the interests of a minority, which organizes its state apparatus for the oppression of the overwhelming majority of the workers, we are making the first attempt in world-history to organize labor in the interests of the laboring majority itself. This, however, does not exclude the element of compulsion in all its forms, both the most gentle and the extremely severe. The element of state compulsion not only does not disappear from the historical arena, but on the contrary will still play, for a considerable period, an extremely prominent part. As a general rule, man strives to avoid labor. Love for work is not at all an inborn characteristic: it is created by economic pressure and social education. One may even say that man is a fairy lazy animal. It is on this quality, in reality, that is founded to a considerable extent all human progress; because if man did not strive to expand his energy economically, did not seek to receive the largest possible quantity of products in return for a small quantity of energy, there would have been no technical development or social culture. It would appear, then, from this point of view that human laziness is a progressive force, old Antonio Labriola, the Italian Marxist, even used to picture the man of the future as a 'happy lazy genius'. We must not, however, draw the conclusion from this that the party and the trade unions must propagate this quality in their agitation as a moral duty. No, no. We have sufficient of it as it is. The problem before the social organization is just to bring 'laziness' within a definite framework, to discipline it, and to pull mankind together with the help of methods and measures invented by the mankind itself" (Trotsky 2010, 147-148).

A lot has been said and written about the laziness of the Russian muzhik. Take, for example, the observations made by Ivan Goncharov on the life of the inhabitants of Oblomovka: "They endured labor as a punishment laid upon our forefathers in times gone by, but they could not love it, and where there was the chance always avoided it, finding this both possible and proper". Unlike others, Trotsky was the one to expand "the laziness of the Russian muzhik" on the entire humanity. Of course, he was disingenuous when doing that. The formative years of the Soviet regime saw the Bolsheviks' naive faith that the working class and the peasantry would readily support them and start working free of charge die away. It turned out that they were wrong, and that the only way to make people work was to coerce them. Thus, no matter the statements made by the authors of the abovementioned textbook, the true intention behind the enactment of the Labor Code was not to protect the labor, but to coerce the people into working hard. That is why "the only way to attract the labor power necessary for our economic problems is to introduce compulsory labor service" (Trotsky 2010, 150). A few lines later is the only occasion on which Trotsky mentions the Constitution and the Labor Code that sketch compulsory 
labor service (Trotsky 2010, 150), which is very characteristic of the legal consciousness (if it can be called so) of the Bolsheviks of his time: law, despite being a means of normalizing violence and coercion, cannot play the first fiddle to force, for there is always a way to use violence lawlessly.

The next crucial thing is that, according to Trotsky, under the proposed labor organization, a person loses his individuality to such an extent that he is no longer capable of even taking care of the everyday necessities of life at his own discretion, with the entire populace becoming nothing more than just a "reservoir of the necessary labor power an almost inexhaustible reservoir" (Trotsky 2010, 150). People turn into labor power they are there to work and that is their only value. A person who is a carrier of labor power has no right to use it as he thinks best. Trotsky wrote that special organizations for the application of the principle of compulsory labor service had been set up (without ever mentioning the Labor Code), adding that they were still only in the embryo stage. The utilization of labor-power must be to the last degree economical. For instance, the government has to see that "the transference of mobilized labor-power should take place over the shortest possible distances - i. e., to the nearest sectors of the labor front" (Trotsky $2010,152)$. Thus, Trotsky denies the freedom of labor in its entirety. "It is necessary once for all to make clear to ourselves that the principle itself of compulsory labor service has just so radically and permanently replaced the principle of free hiring as the socialization of the means of production has replaced capitalist property" (Trotsky 2010, 152).

It appears that Trotsky understood the attractiveness of the word "freedom" as opposed to the word "coercion" as he used the former to debunk the bourgeois-liberal concept of freedom. "Free labor meant labor which might be 'freely' bought in the market; freedom was reduced to legal fiction, on the basis of freely-hired slavery. We know no other form of free labor in history... For the liberal, freedom in the long run means the market" (Trotsky 2010, 156). We will not say Trotsky is completely wrong here. Indeed, under socialism, planned economy is a conditio sine qua non, with markets being virtually non-existent. "If organized economic life is unthinkable without compulsory labor service, the latter is not to be realized without the abolition of fiction of the freedom of labor, and without the substitution for it of the obligatory principle, which is supplemented by real compulsion" (Trotsky 2010, 158). That is quite right. It is not the difficulties caused by civil war, nor is it economic dislocation (both temporary phenomena in their essence), but the planned economy - the basic principle of socialism - that inevitably leads to the introduction of forced labor. That is why it is necessary that labor be militarized. The term "militarization" itself, Trotsky explains, brings up analogies with the organization of an army, which should act as a prototype for the proper organization of labor. Moreover, the army should be actively involved in lightening the burden of economic chores. "Naturally, the military apparatus as such is not adapted directly to the process of labor. But we had no illusions about that. Control had to remain in the hands of the appropriate economic organs; the army supplied the necessary labor power in the form of organized, compact units, suitable in the mass for the execution of the simplest homogeneous types of work: the freeing of roads from snow, the storage of fuel, building work, organization of cartage, etc., etc." (Trotsky 2010, 170). This proposal turned out to be very efficient and easily implementable: throughout the Soviet years, the military was actively assigned to assist the government with performing a variety of economic tasks. 
It is interesting to note, from the point of view of the Bolshevist ideology, how Trotsky "exposes" the views of a certain Menshevik, Abramovich. "Wherein does your socialism, Abramovich cries, 'differ from Egyptian slavery? It was just by similar methods that the pharaohs built the pyramids, forcing the masses to labor. Truly an inimitable analogy for a 'socialist'! Once again the little insignificant fact has been forgotten - the class nature of the government! Abramovich sees no difference between the Egyptian regime and our own. He has forgotten that in Egypt there were pharaohs, there were slave-owners and slaves. It was not the Egyptian peasants who decided through their soviets to build the pyramids; there existed a social order based upon hierarchical caste; and the workers were obliged to toil by a class that was hostile to them. Our compulsion is applied by a workers' and peasants' government, in the name of the interests of the laboring masses" (Trotsky 2010, 191). Trotsky here is completely sincere and self-righteous, believing his reference to the class nature of political authority to be irrefutable. Therefore, "when we say to the turner Ivanov, 'you are bound at once to work at the Sormovo factory; if you refuse, you will not receive your ration', what are we to call it? Economic pressure or legal compulsion? He cannot go to another factory, for all factories are in the hands of the state, which will not allow such a change. Consequently, economic pressure melts here into the pressure of state compulsion" (Trotsky 2010, 187). It is of note here that for Trotsky legal coercion is synonymous with state repression. As he polemizes with Abramovich on the beneficence of compulsion, he exclaims: "In point of fact, under socialism, there will not exist the apparatus of compulsion itself, namely, the state: for it will have melted away entirely into a producing and consuming commune. Nonetheless, the road to socialism lies through a period of the highest possible intensification of the principle of the state. And you and I are just passing through that period. Just as a lamp, before going out, shoots up in a brilliant flame, so the state, before disappearing, assumes the form of the dictatorship of the proletariat, i. e., the most ruthless form of state, which embraces the life of the citizens authoritatively in every direction" (Trotsky 2010, 190). Trotsky indeed was a brilliant orator and a talented publicist. However he, like many Russian Marxists, fell into the trap of class theory, which he perceived as absolutely true and indubitable. For him, those who questioned this theory were either fools or enemies. The only proper way to deal with this kind of people was to exterminate them. Unlike Marx and Engels, whose main occupation was to theorize about such subjects as class struggle, the dictatorship of the proletariat, and the inevitability of violence, Trotsky, as the head of the Soviet of the National Economy, was there to give obligatory orders. There were overtones of Jesuitism in many of his speeches. He completely deprived man of his legal personality. The Legend of the Grand Inquisitor involuntarily comes to mind. But he will not stop here: those abused should enjoy being violated or, at least, be grateful to the abuser - the state. After all, what is essential here is who resorts to violence and for what purpose. In Trotsky's case, the government applies violence in order to secure the interests of its victims and the advent of the future welfare society. Moreover, in the proletarian state, the proletariat is expected to force itself to abide by the new rules (something along the lines of Rousseau's "general will"). Therefore, there is no way that the proletariat could be unjust to itself - only to a bunch of irresponsible proletarians whose existence did not alter the reality on the ground. As regards the peasants, Trotsky's cynicism about their fate appears to have no limits: times are hard nowadays for the peasantry, but "under every other regime it would be infinitely more difficult for them than under the Bolsheviks" (Trotsky 2010, 128). The Soviet regime, which had 
driven away the landlords, in its turn "imposes new duties upon the peasantry, and demands sacrifices from them" (Trotsky 2010, 126). The young proletarian state has to solve the most complicated questions, the answers to which are not to be found in any book. "We are now only beginning, together with you, to write that book in the sweat and the blood of the workers" (Trotsky 2010, 167).

Let us now revert to the aforementioned article by Evgenii Khokhlov written ninety years after the release of Trotsky's pamphlet. What stands out from the very first glance is the fact that, unlike Trotsky, Khokhlov is a lawyer, and a legal theorist at that. Whereas it is only once in passing that Trotsky mentions the Constitution and the Labor Code in his book, Khokhlov bases his reasoning predominantly on the results of his analysis of legal norms and court practices relevant to the organization of labor. The Decree on Workers' Control issued on November 14, 1917 is usually considered the first regulatory enactment in the field of labor management. If we look at this decree from the "rally point of view" of 1917, it may well be found to reflect the famous "return the factories back to the workers" slogan. This is what a formalistic rendering of the decree would make you conclude. Indeed, under this decree, factory workers became entitled to form workers' control units vested with very broad jurisdiction, such as defining workload standards, exercising control over business correspondence, forcing factory owners to report regularly on their activities, etc. Decisions made by workers' control units were binding on all and could be overruled by higher workers' control organs. And here is where it gets interesting. Under the Decree on Workers' Control, the hierarchical system of workers' control units was based on the notion of a highly centralized authority. What matters here the most is not handing over control over production management to the workers, but the establishment of governmental economic control - workers' control units essentially became part of state apparatus. Here is the conclusion Khokhlov comes to: "Thereby, thanks to the system of workers' control units, the Bolsheviks managed to implement their party policy guidelines, namely to centralize economic governance in the hands of the proletarian state. It is of note here that the task of achieving economic centralization had been fulfilled even before the nationalization of industries took place... Therefore, under these circumstances, the term 'control' had to be interpreted in a very broad sense - as a matter of fact, the term became synonymous with 'administration"' (Khokhlov 2010, 59). We are sure that if Trotsky had read these lines, he would not have objected to them: "yes, we did the right thing; there was no other way to do it". Still, after having considered the very same facts, Khokhlov came to a conclusion Trotsky would never have come to: "It is just on the basis of the above examples that we may conclude that the first weeks and months of the Soviet regime brought about a significant deformation of the subject composition of labor relations which had been emerging within the framework of an undersocialized economy" (Khokhlov 2010, 61). Trotsky would certainly ridicule Khokhlov and include him among the pathetic Mensheviks with no knowledge of the ABCs of the proletarian revolution. But, had he used the word "deformation" in such a context one hundred years ago, perhaps he would have risked much more than just being counted among the Mensheviks.

Khokhlov further lays special emphasis on the development of great importance not only for the labor law in general but for the Soviet law in particular, namely the Bolsheviks' rejection of contractual relations. Whereas for Trotsky the abolishment of contractual regulations by the state was definitely a good move, it was a disaster for the law as such. However, the development was quite in line with the logic behind the actions of the proletarian 
state. "The logic behind this move is obvious: since the rational economic organization requires the implementation of centralized production planning and centralized economic development, as well as because labor is a factor of production, both the distribution of labor power and its productive use are subject to centralized planning and state regulation" (Khokhlov 2010, 68). From this point of view, Trotsky was completely right when he demanded a forced redistribution of labor resources, i.e. people capable of working.

It is not within the scope of this paper to follow Khokhlov's analysis of the Labor Code (those interested may refer to his article), but we would like to draw attention to some of its main points.

The Code declares the right of the people to labor, which essentially is nothing but the establishment of the duty to work. Sure, matters could not be otherwise, for the aim of the Code was the establishment of labor conscription. The Code itself starts with section one entitled "On Labor Conscription". We proceed from the premise that the authors of the Code were conversant in Russian and could express themselves explicitly. According to Vladimir Dal, "conscription" denotes obligation, duty, and that which is to be fulfilled or served, while in accordance with Sergey Ozhegov's dictionary, the meaning of the term is social or public duty executed by the populace. Hence, the Code is not about the right to work - it is about the duty to work, the forced labor. "Overall, we can conclude that it was not just the 'duty to work - right to labor' hierarchy that was unveiled by the Code, but the complete determination of 'right' by 'duty"' (Khokhlov 2010, 77).

The Code establishes the possibility of transferring a worker or a group of workers between facilities located either in the same area or in a different area. Self-dismissal was substantially limited. Although part-time work was not prohibited, remuneration could only be received once at one workplace (this provision was apparently intended for workaholics). Thereby, the Code was about the right of the state to practice forced labor rather than the protection of worker's rights. As a quite logical result, the militarization of labor set in, forcing labor not only on the "bourgeois elements", but the "politically unconscious" proletarians themselves. Naturally, this kind of coercion led to a massive increase in work aversion on the part of the people, which in its turn provoked more government repressions. As for salary, it could not act as a stimulating factor for productivity growth for purely objective reasons, among which the main ones were the depreciation of money and the labor policy of the state. In the words of Trotsky, "in the present difficult period the system of wages is for us, first and foremost, not a method for guaranteeing the personal existence of any separate worker, but a method of estimating what that individual worker brings by his labor to the labor republic" (Trotsky 2010, 166).

Apparently, Khokhlov's findings are in conjunction with the conclusion Trotsky came to. The emergence of the "administrative and bureaucratic system of labor management" was provoked by neither civil war nor the ensuing devastation. Things could not be the other way around, for in the genesis of this system was reflected the very essence of the communist ideology, namely the desire to ensure the functioning of the whole society on the basis of reason, which in the field of economics took the form of purposeful production planning coupled with the distribution of products from a single center - the state. Here is where the whole idea of the militarization of labor stems from. Indeed, militarystyle administration "has for centuries been providing us with shining examples of how broad masses of the people had to be organized in order to achieve a single common objective" (Khokhlov 2010, 106-107). Trotsky would definitely agree with the above state- 
ment. As for the claim that, under this kind of labor administration, there would be no place for an individual personality, Trotsky would easily consider it irrelevant.

3. Conclusion. It appears from everything that has been said above that the legal views of Bolshevism essentially remain within the realm of Russian tradition: law means coercion and it is only worthwhile as long as there is someone to coerce; law becomes meaningless with the advent of universal prosperity (either in the form of communism or with the vanishing of all evil). Such a view on the law has been dominant throughout the Soviet era, for it corresponded to the principles the socialist society functions on.

Whilst being nothing exceptional, Khokhlov's views definitely reflect the changes that have been taking place in post-Soviet Russia. For all the flaws and shortcomings of the modern Russian society, the principles that govern its functioning, albeit far from being fully implemented, do require the existence of law. Gradually the idea that law is not so much coercion as a form of existence of society started gaining ground. Law is increasingly associated with order, protection, and the freedom of man. We want to believe that we will not turn off this road.

\section{References}

Chistiakov, Oleg I., Kukushkin, Iurii S. 1971. History of the State and Law of the USSR. Vol.2. Moscow, Iuridicheskaia literature Publ. (In Russian)

Kharkhordin, Oleg V. (ed.). 2002. The Concept of State in Four Languages. St. Petersburg, Moscow, Letnii sad Publ. (In Russian)

Khokhlov, Evgenii B. 2010. “Theory and Practice of the Organization of Labor during the Early Years of the Soviet Regime". Russian Yearbook of Labor Law 6: 49-107. (In Russian)

Kistiakowsky, Bogdan A. 1990. "In Defense of Law". Vekhi: sb. statei o russkoi intelligentsii. Moscow, Novoe vremia Publ., Zhurnal “Gorizont”. (In Russian)

Montesquieu, Charles. 1955. Selected Works. Moscow, Politizdat Publ. (In Russian)

Pipes, Richard. 2000. Property and Freedom. Rus. Ed. Moscow, Moskovskaia shkola politicheskikh issledovanii Publ. (In Russian)

Rozanov, Vasilii V. 1990. Selected Works in Two Volumes. Vol. 2. Moscow, Pravda Publ. (In Russian)

Szpoper, Dariusz. 2003. Pomiędzy caratem a snem o Rzeczypospolitej. Myśl polityczna i działalność konserwatystów polskich w guberniach zachodnich Cesarstwa Rosyjskiego w latach 1855-1862. Gdańsk, Arche Publ.

Taranovsky, Fedor V. 2004. History of the Russian Law. Moscow, Zertsalo Publ. (In Russian)

Tarkowski, Mikołaj. 2018. Polacy na Litwie i Białorusi pod rzadami Aleksandra II (1855-1881). Studium historyczno-prawne. Gdańsk, Arche Publ.

The Russian Orthodox Church. n. d. "The Basis of the Social Concept". Accessed May 5, 2019. https://mospat.ru/en/documents/social-concepts.

Tomsinov, Vladimir A. 2003. History of the Russian Political and Legal Thought of the $10^{\text {th }}-18^{\text {th }}$ Centuries. Moscow, Zertsalo Publ. (In Russian)

Trotsky, Leon D. 2010. Terrorism and Communism. St. Petersburg, Azbuka Publ. (In Russian)

Received: September 19, 2018

Accepted: August 27, 2019

Authors' information:

Igor Yu.Kozlikhin - Dr. Sci. in law, professor; igkoz52@mail.ru

Valerii V.Pugachev - Master of laws; seselj@bk.ru

Oleg A.Zayachkovskii — PhD in law, associate professor; ozayachkovskii@kantiana.ru

Dariusz Szpoper - Dr. Sci. in law, professor; dar.szpoper@gmail.com 